\title{
Effects of nutrition and genetics on the composition of the body
}

\section{By D. LISTER, ARC Meat Research Institute, Langford, Bristol BS $8{ }_{7} D Y$}

Gulick (1922) noticed that amongst people there were 'easily fattening and difficultly fattening types'. He included himself with the latter for his weight had remained fairly constant despite his having had a very copious diet over the years. Sixty years earlier Lawes \& Gilbert (1859) had reported something of the same phenomenon in farm animals and moreover had concluded that the easily fattening types deposited more of their fat subcutaneously relative to the internal depots, which were more pronounced in 'difficultly fattening types'. I have used this observation to classify various of the breeds of farm animal species into 'easily fattening and difficultly fattening types', but it is clear that such a classification can be used to predict far more about the metabolic and physiological basis of body type. This is the subject of a separate paper (Lister, 1977). In passing it is worth noting that since in any mixed population there will be individuals who differ appreciably in the ways in which they partition their total fat between the various sites, the measurement of any one, e.g. subcutaneous fat by skinfold thickness, can never predict with complete accuracy the total body fat. The predictive value of skinfold thickness should, however, be higher in women who possess more of their fat subcutaneously, and this appears to be the case (Durnin \& Womersley, 1974).

Fig. I shows the so-called Fat Partition Index which I have constructed from information derived from the results of the complete anatomical dissections of carcasses containing more than $18 \%$ fat at which point Callow (1948) considered the stable phase of fattening to begin. All the dissections were carried out at the Meat Research Institute to a standard procedure which has often been described (see Report of Major Beef Research Project, I965) and I am grateful to Dr R. W. Pomeroy and $\mathrm{Mr} \mathrm{D}$. R. Williams for allowing me to consult and use their records.

Nutritionists have long been aware, as it has already been noted, of individual differences in metabolism and physiology but have been unable to provide an objective scheme to classify them. The Fat Partition Index (FPI) would seem to offer some possibilities. It appears to be, to some extent, independent of mature lean body size (see, for instance, the values for Jersey and Friesian cattle which differ appreciably in size) and the association with genotype is not explained by the variation in total fatness from one breed to another (see Table I). Although 'carcass' data are not available to demonstrate the relevance of a Fat Partition Index for the human being, I am firmly of the opinion that there exist the 'metabolic' counterparts of Pietrain pigs, Friesian cattle or Suffolk sheep in the human population. 


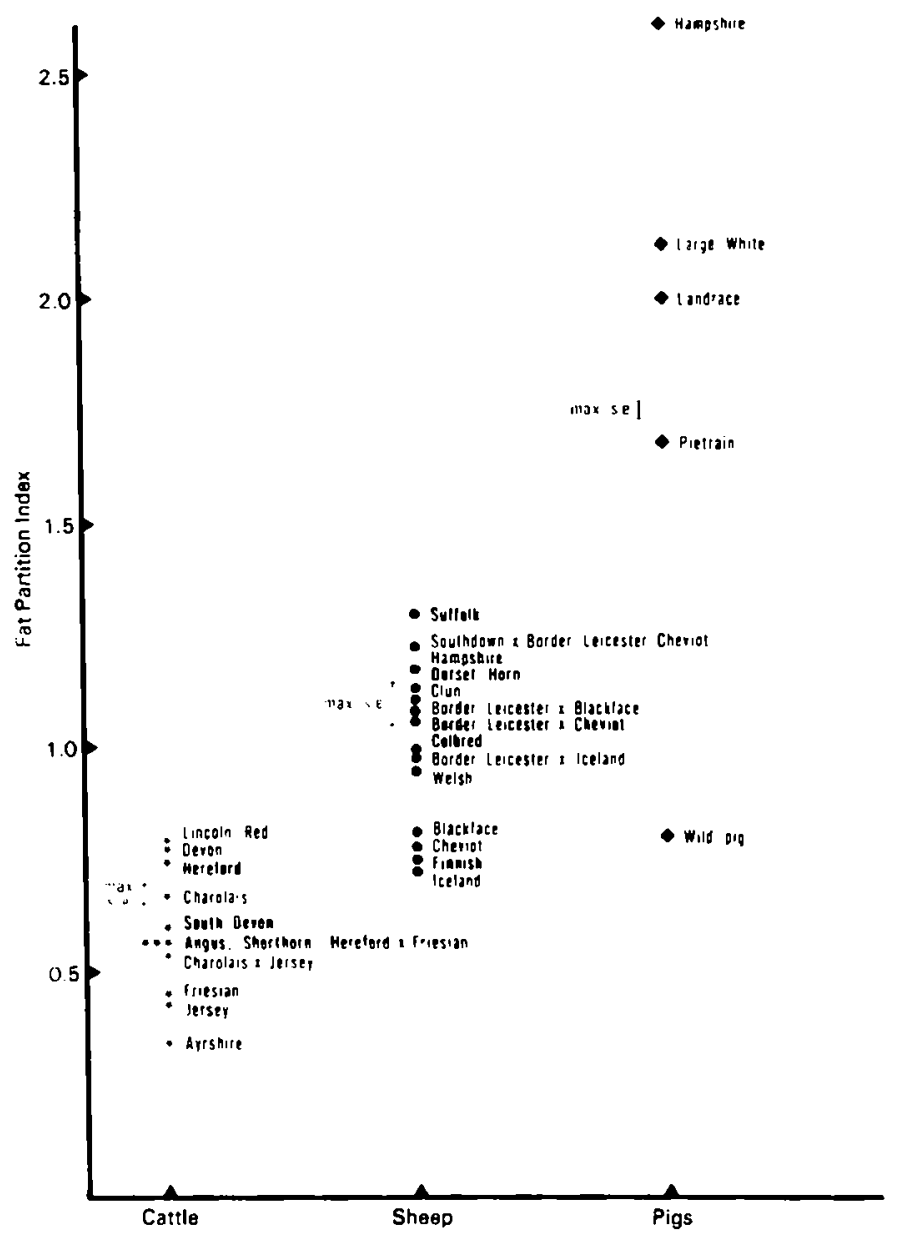

Fig. I. The Fat Partition Index in farm animals. (The index is the quotient obtained by dividing the weight of dissectible subcutaneous fat by the sum of the weights of intermuscular, perinephric and inguinal fat in a carcass.)

Table $\mathrm{i}$. The effect of breed on the deposition and partition of carcass fat (cattle)
s.s.
d.f.
m.s.
F. ratio

Total fat

Between breeds

Within breeds

$\begin{array}{rrrr}2356 \cdot 53 & 7 & 336.65 & 6 \cdot 16^{\bullet \bullet} \\ \text { II } 092 \cdot 45 & 203 & 54.64 & \\ \text { I } 344^{8.98} & 210 & & \end{array}$

Fat partition index

Between breeds

Within breeds

$\begin{array}{rrrr}4.2899 & 7 & 0.6129 & 60.13 \\ 2.0689 & 203 & 0.0102 & \\ 6.3589 & 210 & & \end{array}$

Significant effect of breed ${ }^{\bullet P} P 00.01 ; \bullet \bullet P<0.001$

We have used the Fat Partition Index to identify the most appropriate animals for investigating the efficiency of growth and metabolic type of farm animals. An 
experiment, now in its second year, is using Hampshire and Southdown sheep as examples of larger and smaller easily fattening types for comparison with Cheviot and Scottish Blackface and has demonstrated the predictive value of the FPI. A similar experiment has recently been started using a similar principle to examine different breeds of cattle. But our most detailed observations so far have been collected from pigs. Some of these will now be described.

Pietrains are amongst the leanest pigs commercially available and contain up to $10 \%$ more muscle in their carcasses than those of conventional Large White pigs of the same, $90 \mathrm{~kg}$, live weight. We now know that this results from the smaller voluntary feed intake of Pietrain pigs and their inability to deposit fat in the same quantities as Large Whites. Lean deposition continues at a similar rate in both breeds. When Large Whites are pair fed to the intake of Pietrains this serves only to reduce the amount of deposited fat, though not to the same level as the Pietrain. Lean deposition is unaffected. Thus at the same live weight, Pietrains are leaner than Large Whites because they are older as a result of the slower growth and their reduced fattening ability (Lister, Wood \& Perry, 1974; Perry, 1975).

There is much debate in 'pig circles' whether the selection of pigs for leanness within a breed is achieved by the same route as Pietrains achieve theirs. Certainly if the FPI is any corroborative guide concern has been expressed by many that in the quest for leaner pigs, selection against backfat thickness has 'moved' more fat into intra abdominal depots (Braude, 1976). Evidence from Norway and the USA suggests that the outcome of selection depends on the starting point. Selection against fat in fatter animals can bring about both a reduction in fat and enhanced rates of lean deposition (Hetzer \& Miller, 1973a,b; Standal, Vold, Trygstad \& Foss, 1973) which probably result from an increase in mature lean body size (see Lister, 1976). Selection for increased leanness in pigs which are already lean is likely to lead only to a further curtailment of fat deposition without altering the capacity for lean production, that is, by a route reminiscent of the Pietrain.

More interesting, perhaps, from the nutritional point of view is the response to dietary protein and energy of the animals showing extremes of body type. The fattest pigs in Hetzer \& Miller's experiments were Durocs and the leanest were Yorkshires. They had arrived at these conditions over at least 10 generations of selection. Amongst these somatotypes a striking response to added dietary protein (Davey \& Morgan, 1969) was to be observed only in the leanest Yorkshires which retained significantly more nitrogen. Responses to increased dietary energy (Davey, Morgan \& Kincaid, 1969) could be observed in both somatotypes. The fattest Durocs deposited slightly more protein and appreciably more fat on the higher energy diet. The Yorkshires retained slightly more extra protein than the Durocs but considerably less fat.

Webster and his colleagues (Pullar \& Webster, 1974; Radcliffe, Webster, Dewey \& Atkinson, 1975) observed something of the same in their work on Zucker and lean rats. In their experiments rats were pair fed the same diet, or allowed free access to it, or to isoenergetic diets containing 15 or $30 \%$ casein. Fat rats allowed free access to food containing normal or increased protein retained $\mathrm{N}$ at the same 
rate as lean rats but dietary energy to a greater extent. When they were pair fed to the lower intake of the lean rats they retained considerably less energy and slightly less $\mathrm{N}$. Lean rats fed $30 \%$ casein retained much more $\mathrm{N}$ and slightly more energy than those of their number which received $15 \%$ casein.

In animal production the efficiency of food use is considered to depend on the energy costs of maintenance and of the unitary deposition of protein and fat. There is evidence that genotype probably influences the maintenance requirement but Kielanowski (1972) concludes that the most important genetic factor is the rate of growth. The reduced net daily energy cost of maintenance is undoubtedly an important contributor to the efficiency of the growth of boars whose higher heat production is offset by their rapid growth, but the evidence that genetic differences in maintenance or energy requirements for growth are inconsequential is by no means certain (Garrett, 1971). Fasting metabolism may not be a good base from which to predict energy requirements for growth (Webster, 1976) and it is possible that the response of different genotypes to the procedures used for the measurement of heat production seriously influence the validity of the measures obtained. It is a common observation, for instance, that animals confined in metabolism crates rarely eat the same quantities of feed which they would consume in their usual housing. Our experience with stress-sensitive breeds of pig such as the Pietrain and even with Large White pigs suggests that neuro-endocrine responses are altered for prolonged periods of time despite training and conditioning and the apparently relaxed state of the animals under investigation. Work in our laboratory on hormonal responses to stress and the substrates used for energy purposes strongly supports the general notion that metabolic differences between genotypes are of profound importance in the control of growth and body composition, and may be reflected in rates of protein as they are in hormone turnover (Lister, 1976).

The effects of diet on heat production and growth are still not clearly identified. Miller \& Payne's (1962) observation on the 'luxuskonsumption' phenomenon did not obtain universal acceptance yet interest in the phenomenon has grown recently. McCracken \& Gray's (1976) results showed how the efficiency of utilization of the extra energy intake of a low protein diet was decreased to 0.66 from 0.86 on a normal diet fed isoenergetically. We have seen something similar in an experiment comparing the performance of boars and gilts of the Large White (LW) and Gloucester Old Spot (GOS) breeds receiving the same amount of crude protein $(\mathrm{CP})(\mathrm{N} \times 6.25)$ daily and approximately $30 \%$ different levels of energy, the difference being provided by maize starch. Gloucester Old Spot pigs which are somewhat uncommon in commercial pig practice were used because their FPI suggested them to be one of the most 'easily fattening' of the breeds of pig available today in the UK. The Large White pigs came from a herd noted for its carcass leanness, speed and efficiency of growth, i.e. a strain likely, on the basis of arguments presented above, to be developing some metabolic and physiological characteristics of the Pietrain. Preliminary results show that on the normal commercial diet (Dalgety-Crosfield Ultra Grow 35) fed to a live weight scale, the 
pigs grew in the order LW ${ }^{\circ}$ (fastest), LW $\odot$, GOS $ठ^{*}$, GOS $Q$. On the high energy diet the order was reversed with the GOS $\&$ gaining $30 \%$ more than they did on the control diet whilst the LW $\delta$ gained the same. At this stage the results suggest an explanation in terms of an increased heat production of the lean, rapidly growing boars but this will need confirmation from our investigations of body composition. This finding lends further support to the view that individuals vary in their energy expenditure in response to diet and that those most prone to the 'futile energy cycle' effect are most likely to possess a capacity to limit their deposition of fat.

Appetite, dietary energy and protein contribute in various ways to the development of body size and form and the evidence presented here, though by no means conclusive, suggests that differences in metabolism from one animal to another, and more conspicuously from one genotype to another, influence the response to the intake of feed and its composition. Munro (1964) attempted to explain the interactions between dietary protein, energy intake and $\mathrm{N}$ retention. $\mathrm{He}$ concluded that the energy content of the diet influences mainly the reutilization of amino acids during the post absorptive period. Meals containing carbohydrate induce a temporary retention of $\mathrm{N}$ probably as a labile form of muscle $\mathrm{N}$. Hormones also have an important role. The specific action of dietary carbohydrate is brought about by an increase in circulating insulin concentration. Growth hormone and androgens will also cause the deposition of labile proteins in muscle. $\mathrm{N}$ is conserved in the body not only by insulin in the $\mathrm{N}$-sparing effect of carbohydrate, but also by the elevation of circulating free fatty acid levels in the presence of a small rise in circulating insulin levels (Cahill \& Aoki, 1976).

Some of our most recent work suggests that such specific mechanisms might separately be employed by different genotypes to obtain their peculiar phenotypic characters. 'Difficultly fattening' animals such as the Pietrain pig mobilize and use fatty acids for energy purposes to a greater extent than Large Whites (Wood, 1973; Wood, Gregory, Hall \& Lister, 1977). This is reflected in the amount and composition of their depot fats and also in their hormonal profiles. The sympathetic nervous system is more easily stimulated in Pietrains by emotion, physical exercise or drugs (Lister, Hall \& Lucke, 1975; Lucke, Hall \& Lister, 1976) and the secretion and utilization of thyroid hormones is raised (Moss, 1975; Lister, 1976). Fasting levels of insulin are lowered and plasma FFA are raised in Pietrains relative to Large White and Gregory (1976) has reported a high correlation between the proportions of fat and muscle in carcasses and the fasting insulin level. Thus one might consider, for example, the roles of insulin in lipogenesis, protein accretion and the $\mathrm{N}$-sparing effect of carbohydrate to be important in fatter animals. In lean animals such roles must be curtailed perhaps as a consequence of a greater dependence on the sympathetic system and fatty acid metabolism for the provision of energy. This may also, in conjunction with the reduced levels of circulating insulin, provide a mechanism for the conservation of body N (Sapir, Owen, Pozesky \& Walser, 1974).

There are clearly several indications, therefore, that differences between 
somatotypes especially in their FPI are symptomatic of their metabolic and hormonal attributes. As yet they can only be described in gross physiological terms but they offer potentially important links between fundamental biochemistry and growth and development. Just as Haldane (1929) considered that for every type of animal there is a most convenient size, it seems that the form and metabolism of that body of convenient size is just as surely ordered.

\section{REFERENCES}

Braude, R. (1976). In Meat Animals: Growth and Productioity, p. 25. [D. Lister, D. N. Rhodes, V. R. Fowler and M. F. Fuller, editors]. New York \& London: Plenum.

Cahill, G. F. \& Aoki, T. T. (1976). In Meat Animals: Grocoth and Productioity, p. 221. [D. Lister, D. N. Rhodes, V. R. Fowler and M. F. Fuller, editors]. New York \& London: Plenum.

Callow, E. H. (1948). Y. agric. Sci., Camb. 38, 174.

Davey, R. J. \& Morgan, D. P. (1969). F. Anim. Sci. 28, 831.

Davey, R. J., Morgan, D. P. \& Kincaid, C. M. (1969). J. Anim. Sci. 28, 197.

Durnin, J. V. G. A. \& Womersley, J. (1974). Br. F. Nutr. 32, 77.

Garrett, W. N. (1971). J. Anim. Sci. 32, 45r.

Gregory, N. G. (1976). A physiological approach to some problems in meat production. Ph.D. thesis. University of Bristol.

Gulick, A. (1922). Am. F. Physiol. 60, 371.

Hetzer, H. O. \& Miller, R. H. (1973a). F. Anim. Sci. 35, 730.

Hetzer, H. O. \& Miller, R. H. (1973b). F. Anim. Sci. 35, 743.

Haldane, J. B.S. (1929). Possible Worlds and Other Essays, p. 18. London: Chatto \& Windus.

Kielanowski, J. (1972). In Proceedings of II Congress Mundial de Alimentacion Animal, IV Sesiones Plenarios, p. 911 . Madrid.

Lawes, J. B. \& Gilbert, J. H. (1859). Phil. Trans. R. Soc. 149, 494

Lister, D. (1976). In Meat Animals: Growth \& Productivity, P. 355. [D. Lister, D. N. Rhodes, V. R. Fowler and M. F. Fuller, editors]. New York \& London: Plenum.

Lister, D., Hall, G. M. \& Lucke, J. N. (1975). Lancet i, 5 I9.

Lister, D., Wood, J. D. \& Perry, B. N. (1974). In Proceedings of the 25th Meeting of European Association for Animal Production. Copenhagen: Pigs Commission.

Lucke, J. N., Hall, G. M. \& Lister, D. (1976). Br. J. Anaesth. 48, 297.

McCracken, K. J. \& Gray, R. (1976). Proc. Nutr. Soc. 35, 61A.

Miller, D. S. \& Payne, P. R. (Ig62). F. Nutr. 78, 255.

Moss, B. W. (1975). Some physiological effects of the intensive husbandry of pigs. Ph.D. thesis. University of Bristol.

Munro, H. N. (1964). In Mammalian Protein Metabolism. Vol. 1, p. 381. [H. N. Munro \& J. B. Allison, editors]. New York \& London: Academic Press.

Perry, B. N. (1975). F. agric. Sci. Camb. 84, 191.

Pullar, J. D. \& Webster, A. J. F. (1974). Br. Y. Nutr. 31, 377.

Radcliffe, J. D., Webster, A. J. F., Dewey, P. J. S. \& Atkinson, T. E. (1975). Proc. Nutr. Soc. $34,54 \mathrm{~A}$.

Report of Major Beef Research Project. (1965). London: Royal Smithfield Club.

Sapir, D. G., Owen, O. E., Pozefsky, T. \& Walser, M. (1974). F. Clinc. Invest. 54, 974.

Standal, N., Vold, E., Trygstad, O. \& Foss, I. (1973). Anim. Prod. 16, 37.

Webster, A. J. F. (1976). In Meat Animals: Growth \& Productivity, p. 89. [D. Lister, D. N. Rhodes, V. R. Fowler and M. F. Fuller, editors]. New Yort \& London: Plenum.

Wood, J. D. (1973). Anim. Prod. 17, 281.

Wood, J. D., Gregory, N. G., Hall, G. M. \& Lister, D. (1977). Br. J. Nutr. 37, 167. 